\title{
Ghrelin, an endogenous growth hormone secretagogue with diverse endocrine and nonendocrine effects
}

\author{
Sofie F. Bhatti, DVM; Luc M. Van Ham, DVM, PhD; Jan A. Mol, PhD; Hans S. Kooistra, DVM, PhD
}

Cis irculating ghrelin, the natural ligand of GHS-R 1a, is synthesized primarily in the stomach in mammals. The distribution of these receptors is consistent with the role of ghrelin in promoting secretion of $\mathrm{GH}$; receptors are highly expressed in the hypothalamus and pituitary gland and are also distributed in other central and peripheral tissue sites. In addition to strong GH-releasing activity, ghrelin has other actions, including stimulation of lactotroph and corticotroph function, stimulation of appetite, regulation of energy homeostasis, stimulation of gastric motility and gastric acid secretion, regulation of insulin secretion and glucose metabolism, cardiovascular effects, and antiproliferative activity. These properties make ghrelin a candidate for future diagnostic and clinical applications.

In mammals, secretion of GH from the adenohypophysis is regulated by 2 hypothalamic hormones with antagonistic actions: a stimulatory GHRH that is produced in the arcuate nucleus and an inhibitory hormone, somatostatin, synthesized in the paraventricular nucleus. ${ }^{1}$ Both hormones are transported from the hypothalamus to target cells in the pituitary gland via the hypothalamo-hypophyseal portal system in the median eminence. Alternation in secretion of GHRH and somatostatin is responsible for the pulsatile pattern of GH release. ${ }^{2,3}$ Measurement of GHRH and somatostatin in hypophyseal-portal blood in humans and other animals reveals that the episodic pattern of GHRH and somatostatin secretion does not fully account for all pulses of GH secretion. ${ }^{4}$ The amplitude and frequency of GH secretory pulses are regulated by a complex array of external and internal stimuli, including body composition, age, sleep, gender, disease status, menstrual cycle phase, genetic background, and nutritional status. ${ }^{5-7}$

The discovery of ghrelin, the natural ligand of GHS-R la, was an important advance in the understanding of regulation of GH secretion. ${ }^{8}$ Ghrelin has been isolated from tissues of the stomach, where its expression is higher than in any other tissue. ${ }^{8}$ The site of ghrelin production and its molecular structure, which contains an octanoyl group, were initially surprising to investigators.

Received May 12, 2005.

Accepted June 2, 2005

From the Department of Small Animal Medicine and Clinical Biology, Faculty of Veterinary Medicine, Ghent University, Salisburylaan 133, B-9820 Merelbeke, Belgium (Bhatti, Van Ham); and the Department of Clinical Sciences of Companion Animals, Faculty of Veterinary Medicine, Utrecht University, Yalelaan 8, NL3508 TD, Utrecht, The Netherlands (Mol, Kooistra).

The authors thank Dr. A. Rijnberk for assistance with the manuscript.

Address correspondence to Dr. Bhatti.
Apart from its role in stimulating pituitary release of $\mathrm{GH}$, ghrelin has many other actions. The discovery of ghrelin and its various physiologic actions opened new avenues of research, not only in the field of neuroendocrinology, but also in the areas of gastroenterology, immunology, oncology, cardiology, reproduction, cell proliferation and growth, energy homeostasis, and energy balance. In this overview, we summarize recent findings on the physiologic effects of ghrelin in several mammalian species and describe future diagnostic and clinical applications.

\section{Growth Hormone}

Growth hormone, a 191-amino acid, single-chain polypeptide, is synthesized, stored, and secreted by somatotroph cells in the adenohypophysis. ${ }^{9}$ The effects of GH on growth and metabolic functions are mediated through the GH receptor. Growth hormone forms complexes with 2 peripheral GH receptor components, leading to dimerization of the receptor, an event that is necessary for subsequent GH signaling. Growth hormone receptor dimerization elicits an intracellular phosphorylation cascade involving the JAK-STAT (Janus kinase signal transducers and activators of transcription) pathway. ${ }^{10}$

The liver contains abundant GH receptors, and several other peripheral tissues, including muscle and fat, express modest amounts of GH receptors. ${ }^{11}$ In contrast to most other pituitary hormones, the action of GH is not confined to a single target tissue and the hormone has both slow anabolic and rapid catabolic activities. ${ }^{12}$ The catabolic effects are exerted via direct interaction with target cells, resulting in enhanced lipolysis in fat cells, and restriction of glucose transport across the cell membrane, caused by anti-insulin activity. ${ }^{12-14}$ The anabolic effects (ie, growth and cell proliferation) of GH are exerted indirectly, mainly mediated by growth factors known as IGFs or somatomedins. ${ }^{15}$ The liver is the primary source of circulating IGFs. Growth hormone also promotes the production of IGFs in peripheral tissues (eg, muscle, bone, cartilage, kidney, and skin), where they appear to have autocrine and paracrine effects. ${ }^{15}$

Insulin-like growth factors have approximately $50 \%$ amino acid sequence similarity with insulin. ${ }^{16}$ In

\begin{tabular}{ll}
\hline GHS-R 1a & GH secretagogue receptor type 1a \\
GH & Growth hormone \\
GHRH & GH-releasing hormone \\
IGF & Insulin-like growth factor \\
GHRP-6 & GH-releasing peptide-6 \\
GHS & GH secretagogue \\
PRL & Prolactin \\
GHS-R & GHS receptor
\end{tabular}


contrast to circulating insulin, IGFs are bound to plasma proteins, which prolongs their half-life and contributes to their long-term growth-promoting effects. Circulating IGFs are important determinants of body size because they stimulate protein synthesis, chondrogenesis, and body growth. Insulin-like growth factor-1 has an inhibitory effect on GH secretion, most likely by stimulating the release of somatostatin and by a directly inhibitory influence at the level of the pituitary gland. ${ }^{17}$ Additionally, GH has a negative feedback effect on its own production at the level of the hypothalamus. ${ }^{18}$

\section{Synthetic Growth Hormone Secretagogues}

The usual sequence of discovery in endocrinology is isolation of a hormone, cloning of its receptor, and development of analogs of the hormone for clinical use. With ghrelin, this sequence was reversed: first, analogs were synthesized, then the receptor was cloned, and lastly, the natural ligand of the orphan receptor was isolated.

Briefly, in 1975, before the discovery of GHRH, the GH-releasing properties of enkephalins were reported. ${ }^{19}$ Chemical modification of the structure of met-enkephalin led to development of a highly potent GH-releasing hexapeptide, GHRP-6 [(His-DTrp-Ala-Trp-D-Phe-Lys- $\left.\mathrm{NH}_{2}\right)^{3}$ ], in $1980 .{ }^{20}$ One of the most remarkable properties of GHRP-6 was the strong GH-releasing activity induced following oral administration. $^{21}$ The hexapeptide was the basic structure from which synthetic GHSs, of either peptidergic structure such as hexarelin or nonpeptidergic structure such as MK-0677,22,23 were subsequently produced. Currently used synthetic GHSs are highly bioavailable and may be administered via IV, IM, intranasal, SC, oral, and transdermal routes. ${ }^{24}$ Because $\mathrm{GH}$ is a large protein that must be administered via injection or inhalation, administration of synthetic GHSs is often preferred over administration of GH. In addition, GHSs induce a more physiologic pulsatile pattern of $\mathrm{GH}$ release. ${ }^{24,25}$ For example, a single orally administered dose of MK-0677 increases mean 24-hour plasma GH concentrations. ${ }^{21,23,26}$

The synthetic GHSs have potent GH-releasing activity in several species, including humans, mice, rats, swine, goats, cows, and dogs. ${ }^{27-29}$ In humans, nearly all synthetic GHSs induce the release of more GH than does GHRH. ${ }^{24}$ However, the hormone-releasing action of synthetic GHSs is not always specific. ${ }^{24}$ In humans, synthetic GHSs such as GHRP-6 also have a stimulatory effect on the secretion of PRL, ACTH, and cortisol. $^{24,30,31}$ Newer selective GHSs, such as ipamorelin, do not have ACTH- or PRL-releasing actions. ${ }^{32,33}$

Interest in GHSs faded after the isolation and characterization of GHRH in 1982, ${ }^{34,35}$ but was later revived when it was discovered that GHSs operated through receptors that are different from those for GHRH. ${ }^{24,36,37}$ Growth hormone secretagogues and GHRH have strongly synergistic actions, which indicates that synthetic GHSs are not physiologic surrogates of GHRH. ${ }^{38}$ In 1996, GHS-R, a G-protein-coupled 7-transmembrane receptor, was identified. ${ }^{39}$ This receptor has been cloned from cells of the pituitary gland in humans ${ }^{36,40}$ and rats. ${ }^{41}$
Two types of GHS-Rs, which are presumably the result of alternate processing of pre-mRNA, have been identified and designated as receptors $1 \mathrm{a}$ and $1 \mathrm{~b}^{21,36}$ Human GHS-R la shares 96\% and 93\% sequence identity with rat and pig receptors, respectively. The existence of this receptor can be traced to animals in the pre-Cambrian era because amino acid sequences highly similar to those in the human GHS-R la have been detected in teleost fish. ${ }^{42}$ These observations indicate that the GHS-R la is highly conserved across species and likely has an essential biological function. This receptor is largely confined to somatotroph cells in the pituitary gland and to several hypothalamic nuclei (eg, the supraoptic, arcuate, and paraventricular nuclei) in humans and rats. ${ }^{21,36,37,43}$ Messenger RNA encoding GHS-R la has been detected in the pituitary gland, indicating that GHSs can act directly on somatotrophs to stimulate $\mathrm{GH}$ release. This is in accordance with an earlier observation ${ }^{44}$ that GHSs are able to directly stimulate GH release from rat pituitary cells in vitro. The hypothalamic localization of the GHS-R 1a, especially in the supraoptic and paraventricular nuclei, supports the notion that GHSs may also indirectly regulate $\mathrm{GH}$ release by interacting with GHRH-producing neurons, somatostatin-producing neurons, or both, in the hypothalamus. ${ }^{45}$ The GHS-R $1 \mathrm{a}$ is also expressed in other areas of the brain and certain peripheral tissues, ${ }^{46}$ indicating that GHSs may also be involved in other physiologic functions. ${ }^{37,47}$ The importance of the widespread expression of GHS-R $1 \mathrm{~b}$ in endocrine and nonendocrine tissues has not been determined. ${ }^{36,48}$

The GHS-Rs are distinct from the GHRH receptor. $^{36,37,40}$ Although binding of GHRH to the GHRH receptor increases cAMP in somatotroph cells and stimulates GH release via activation of the kinase A pathway, binding of ghrelin and synthetic GHSs to the GHS-R la activates the phospholipase C signaling pathway, leading to an increase in inositol triphosphate and protein kinase $C$ activation, followed in turn by release of calcium from intracellular stores. ${ }^{39}$ Unlike GHS-R 1a, GHS-R 1b does not bind ghrelin or synthetic GHSs, and its function awaits clarification. ${ }^{36,40,48}$

\section{Ghrelin}

The 1999 discovery of the endogenous or natural ligand of the GHS-R, termed ghrelin (ghre is the proto-Indo-European root of the word grow, and relin indicates release), provided a new dimension to $\mathrm{GH}$ research. ${ }^{8}$ Ghrelin causes release of GH in vitro and in vivo. The 28-amino acid peptide was isolated from the stomach, where its expression is higher than in any other tissue. ${ }^{8}$ Although this source may initially seem strange, it should be remembered that most circulating somatostatin is synthesized in the intestines and pancreas and that GHRH was first isolated not from the hypothalamus but from a pancreatic tumor. ${ }^{49}$ Thus, the 3 neurohormones (ie, somatostatin, GHRH, and ghrelin) responsible for regulation of $G H$ secretion are highly expressed in gastrointestinal tissues.

In humans, rats, and domestic animals, expression of ghrelin mRNA and the ghrelin peptide is primarily detected in the enteroendocrine or X-A-like cells of the fundic glands in the stomach, ${ }^{27,50}$ which have been 
renamed Ghr-cells. The cells containing ghrelin do not communicate with the lumen of the fundic gland but, like all enteroendocrine cells, are positioned adjacent to capillaries, indicating that their primary action is secretion of hormone into plasma and not into the intestinal lumen. ${ }^{51}$

The degree of structural heterogeneity of ghrelin among species appears to be minor, suggesting that there is little functional heterogeneity. Such preservation of structure also reflects the physiologic relevance of the peptide. ${ }^{49,50}$ For example, human and rat ghrelin differ in only 2 amino acids (Table 1)..$^{52}$ Alternative splicing of mRNA segments encoding ghrelin yields 2 different peptides, ghrelin and des-Gln14-ghrelin. ${ }^{53}$ The latter is homologous with ghrelin except for the absence of a single glutamine residue. Des-Gln14-ghrelin is expressed in the stomach in low quantities, ${ }^{47}$ but like ghrelin, it increases the intracellular concentration of calcium in cells that express the GHS-R la and increases plasma GH concentrations. ${ }^{8,53}$

Before being secreted, $n$-octanoic acid is added to the third serine residue of ghrelin and des-Gln14ghrelin (Figure 1)..$^{52}$ This acylation step, unique to mammalian species, is essential for binding to and activating the GHS-R $1 \mathrm{a}^{54}$ and hence for the peptide's GHreleasing action. Acylation is most likely also necessary for the other endocrine actions of the ghrelin molecule. ${ }^{47,55}$ Addition of the $n$-octanoyl group confers a hydrophobic property to the $\mathrm{N}$ terminus of the peptide. It has been suggested that the octanoylation of ghrelin is critical to the peptide's ability to cross the bloodbrain barrier. It may also facilitate distribution of the peptide in the brain, although there are presently no data to support this speculation. ${ }^{56}$ Nonacylated ghrelin is found in far greater quantities in human serum than acylated ghrelin, but appears to lack endocrine activity. However, this peptide does have certain nonendocrine cardiovascular and antiproliferative effects, which are likely mediated by binding to a novel and as-yet unidentified GHS-R subtye. ${ }^{57}$ Nonacylated ghrelin inhibits proliferation of human prostate cancer cell lines and neoplastic cell growth in thyroid, breast, and lung tumors. Cardioprotective and negative inotropic effects have also been described. ${ }^{51,57}$

Lower concentrations of ghrelin have been detected in various other tissues, including the intestines,$^{51}$ pituitary gland ${ }^{58}$ hypothalamus, ${ }^{8,59}$ kidney, ${ }^{59}$ placenta ${ }^{60}$ heart ${ }^{49}$ testis,${ }^{61}$ thyroid gland ${ }^{62}$ pancreas ${ }^{63}$ lung ${ }^{64}$ ovary ${ }^{65}$ immune system, ${ }^{66}$ and neoplastic tissue. ${ }^{46}$ The physiologic importance of ghrelin as a paracrine factor in these tissues is under investigation, but an endocrine role for non-stomach-derived ghrelin is thought to be unlikely. Removal of the stomach in humans and rats decreases the plasma concentration of ghrelin by approximately $65 \%$ and $80 \%$, respectively ${ }^{51,67}$ However, plasma ghrelin concentrations gradually increase after gastrectomy. ${ }^{68}$ These findings indicate that the stomach is the major source of circulating ghrelin but that other tissues may increase secretion of ghrelin in a compensatory manner. ${ }^{69}$

\section{Endocrine Effects of Ghrelin}

Ghrelin has pronounced, dose-related GH-releasing actions that are more marked in humans than in other mammals. ${ }^{8,21,27-29,31,51,70-73}$ The GH-releasing activity of ghrelin is greater in vivo than in vitro because ghrelin and GHRH act synergistically, consistent with the fact that their actions are at least partially mediated via different mechanisms. ${ }^{21,74}$ Nevertheless, GHRH activity is required for full expression of ghrelin's GH-releasing activity. ${ }^{21,74}$ The GH response to ghrelin is partially inhibited by GHRH receptor antagonists and disruption of communication between the hypothalamus and pituitary gland, ${ }^{75,76}$ supporting the assumption that the effect of ghrelin on $\mathrm{GH}$ secretion is primarily mediated by GHRH-secreting neurons at the level of thehypothalamus. ${ }^{21,74,76,77}$

In anesthetized rats, ghrelin administered IV stimulates GH release without affecting secretion of other adenohypophyseal hormones. ${ }^{8}$ Also, in cultured rat pituitary cells, ghrelin stimulates GH release in a dosedependent manner without affecting the release of other pituitary hormones, even at high concentrations. ${ }^{8}$ However, in healthy humans, ghrelin is not specific for $\mathrm{GH}$ release because it also has stimulatory effects on lactotroph and corticotroph cells..$^{31,72,78,79}$ The effect of ghrelin on PRL secretion is independent of gender and age and likely results from direct stimulation of somatomammotrophs. ${ }^{72,78,80,81}$ In $\operatorname{dogs}^{28,29}$ and rats, ${ }^{8}$ synthetic GHSs do not stimulate PRL release. This species-related difference may be explained by differences in the number of somatomammotrophs in various species, with humans having a high proportion of those cells. ${ }^{32,82}$ The mechanism by which ghrelin stimulates the pituitary-adrenocortical axis is still unknown, but it is thought to be mediated via the hypothalamus because the stimulatory effect is lost after sectioning of the pituitary stalk. ${ }^{83}$ Ghrelin may also interact with hypothalamic peptides that control ACTH release, probably via arginine vasopressin..$^{55,84,85}$

Table 1-Primary structure of ghrelin in domestic mammalian species.

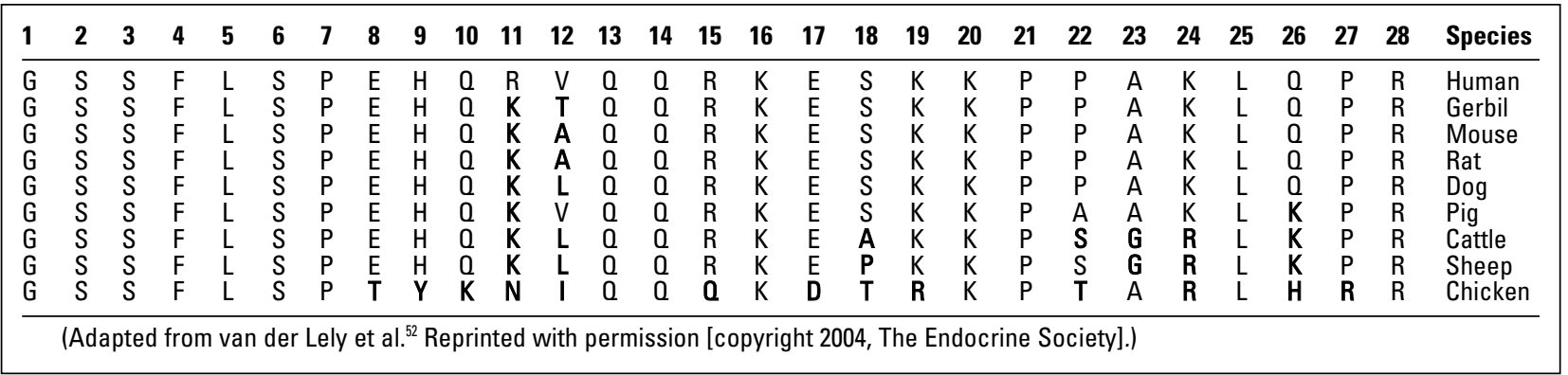




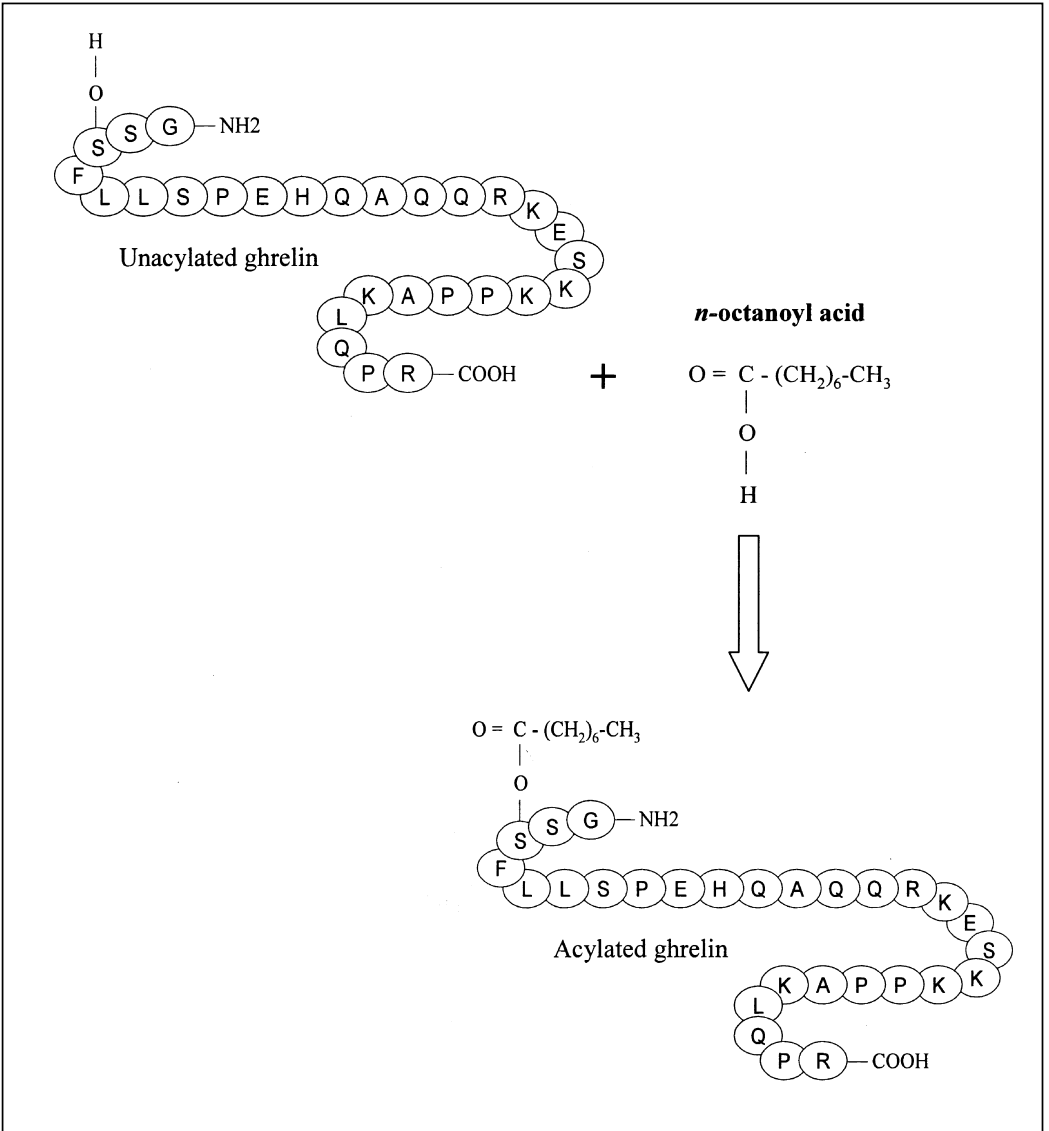

Figure 1-Illustration of acylation of the ghrelin molecule. A hydroxyl group on the serine residue at position 3 of the ghrelin molecule is octanoylated. This esterification is unique to mammals and is essential for ghrelin binding to and activating GHS-R 1a and, consequently, for the GH-releasing action of ghrelin. The other endocrine actions of ghrelin are also likely dependent on acylation of the peptide. (Adapted from van der Lely et al. ${ }^{52}$ Reprinted with permission [copyright 2004, The Endocrine Society].)

\section{Orexigenic Actions and Role in Energy Homeostasis}

Evidence for involvement of ghrelin in regulation of appetite was first detected in humans. Healthy human volunteers reported hunger after administration of ghrelin in a clinical study in which GH release was analyzed. ${ }^{86}$ In rodents, ghrelin stimulates food intake and increases body weight while reducing mobilization of adipose stores. ${ }^{87-89}$ The effects of ghrelin on food intake are likely mediated through mechanisms other than those implicated in GH regulation, compatible with the concept of distinct GHS-R subtypes. ${ }^{87,90}$

Adipocytes traditionally have been viewed as energy depots in which triglycerides are stored during feeding and that release fatty acids during fasting to provide fuel for other tissues. However, it is now known that adipose tissue has major integrative physiologic functions, including secretion of numerous proteins. ${ }^{91,92}$ The realization that adipose tissue has endocrine functions has important implications for our understanding of the associations between excessive body fat and pathologic states such as insulin resistance and type 2 diabetes mellitus. ${ }^{92}$

An important finding that linked central regulation of metabolism to mobilization of peripheral ener- gy stores was the discovery of the adipose hormone, leptin (from the Greek root leptos, meaning thin). Leptin, a peptide hormone discovered in 1994, is produced principally by white adipose tissue. ${ }^{93}$ Leptin crosses the blood-brain barrier to act via receptors in the arcuate nucleus of the hypothalamus to inhibit release of orexigenic neuropeptides and stimulate release of anorexigenic neuropeptides. ${ }^{91,94}$ A direct relationship exists between plasma leptin concentrations and percentage body fat. Plasma leptin concentrations in humans are generally proportional to adipose mass. Decreases in leptin concentrations occur in conditions characterized by loss of adipose mass, such as anorexia nervosa, diet- or exercise-induced weight loss, or starvation. Concentrations of circulating leptin decrease rapidly within 12 hours after initiation of starvation, whereas concentrations increase in response to overfeeding. Thus, plasma leptin concentrations reflect adipose tissue mass and provide a signal that informs the CNS about the body's energy reserves. ${ }^{91}$

The similarities and complementary actions between leptin and ghrelin are intriguing. The effects of ghrelin on metabolism appear to be the opposite to those of leptin. ${ }^{47,87,95,96}$ Leptin reduces food intake and selectively reduces fat mass without altering lean body mass. ${ }^{97}$ Ghrelin, in contrast, increases food intake and selectively enhances fat mass. ${ }^{87}$

Ghrelin stimulates food intake in rodents when administered via central or peripheral routes (ie, intracerebroventricularly or SC), although the effect is more powerful after central administration. ${ }^{87}$ There is evidence that the appetite-stimulating effects of ghrelin are mediated by secretion of 2 potent orexigenic hypothalamic hormones (neuropeptide $\mathrm{Y}$ and agouti-related peptide) and by inhibition of proopiomelanocortin and $\alpha$-melanocyte-stimulating hormone. ${ }^{98-101}$ Furthermore, the orexigenic action of ghrelin is eliminated when the effects of neuropeptide $\mathrm{Y}$ and agouti-related peptide are antagonized. ${ }^{99}$ By stimulating the release of orexigenic peptides and neurotransmitters, ghrelin mediates a novel circuit regulating energy homeostasis. ${ }^{101-105}$

In humans and rats, concentrations of circulating ghrelin decrease in chronic (obesity) ${ }^{106}$ and acute (caloric intake) ${ }^{107}$ states of positive energy balance, whereas ghrelin concentrations increase in states of negative energy balance (eg, fasting) ${ }^{87}$ In cattle, plasma ghrelin concentrations are low 1 hour after feeding and then return to the prefeeding concentration. ${ }^{27}$ In sheep, the preprandial ghrelin surge is higher in animals fed twice daily than in animals fed 4 times daily, indicating that different feeding regimens influence ghrelin concentrations. ${ }^{108}$ The preprandial increase and postpran- 
dial decrease in plasma ghrelin concentrations suggest a possible role for ghrelin as a hunger signal that triggers meal initiation. ${ }^{107}$ Because ghrelin is a potent stimulator of $\mathrm{GH}$ release, these observations are in accordance with the low plasma GH concentrations associated with obesity ${ }^{109}$ and the high concentrations observed in the malnourished and fasting states. ${ }^{110}$

It may be concluded that nutritional state is an important determinant of plasma ghrelin concentration. ${ }^{111}$ Ghrelin peptide reaches ghrelin receptors in the hypothalamo-pituitary region via the general circulation, where it stimulates GH release and regulates energy homeostasis. It is unclear whether ghrelin must cross the blood-brain barrier to influence the activity of these central structures. ${ }^{52}$ In the general circulation, ghrelin is bound to high-density lipoproteins in the serum and presumably to other proteins, such as albumin. Ghrelin may also signal the brain directly, by activating the afferent portion of the vagal nervous system as either an endocrine or a paracrine signal, at the level of the stomach. Ghrelin-responsive GHS-Rs are expressed on gastric vagal nerves, and vagotomy prevents some of the effects of ghrelin on energy balance. On the other hand, the extent and direction of ghrelin transport across the blood-brain barrier may be determined by its unique primary structure. ${ }^{112}$ There is debate among scientists concerning the routes by which ghrelin in the peripheral circulation activates receptors in the CNS of different species.

\section{Gastric Prokinetic Action}

Ghrelin induces strong prokinetic activity in the stomach. ${ }^{113,114}$ The peptide dramatically accelerates gastric and intestinal emptying in rats, and circulating ghrelin concentrations are correlated with gastric emptying time in humans. ${ }^{113}$ In addition, ghrelin stimulates gastric acid secretion. ${ }^{114}$

In that context, structural and functional similarities exist between ghrelin and motilin. ${ }^{115}$ In addition to prokinetic effects on the gastrointestinal tract, both peptides have orexigenic properties ${ }^{116}$ and stimulatory effects on pituitary GH release. ${ }^{117}$ The G-proteincoupled receptors of ghrelin and motilin also have a high degree of structural homology. ${ }^{118}$ In contrast to ghrelin, motilin is primarily expressed in the small intestine. ${ }^{119}$ Motilin stimulates motor activity in the gastric antrum and proximal portion of the duodenum and plays a key role in the regulation of motility between meals. ${ }^{120}$

The gastrokinetic effects of ghrelin and motilin may prove beneficial in the treatment of postoperative gastric ileus. In humans and other mammalian species, abdominal surgery and attendant manipulation of the viscera inhibit gastric emptying and digestive motor activity, which may result in postoperative ileus. Attempts to stimulate smooth muscle activity with prokinetics (eg, cisapride and acetylcholine) are often unsuccessful. ${ }^{114}$ In rats, ghrelin reverses postoperative gastric ileus. ${ }^{113}$

\section{Effects on the Endocrine Pancreas}

Ghrelin and GHS-R la mRNA are expressed in endocrine cells of the pancreas. ${ }^{37,48,121,122}$ Expression of ghrelin has been reported in the pancreatic $\alpha$-cells, ${ }^{121}$ although other investigators have reported that ghrelin is expressed in the pancreatic beta cells. ${ }^{63}$ Ghrelin is not co-expressed with any known islet-derived hormone; thus, ghrelin-producing cells may be a newly recognized type of islet cell. ${ }^{123}$

Published information regarding the effect of ghrelin on insulin secretion in humans and rats is conflicting, ${ }^{121,124,125}$ but most findings suggest that there is a negative association between ghrelin concentrations and insulin secretion. ${ }^{106,107,121,126,127}$ In humans, ghrelin induces a significant increase in plasma glucose concentrations and a decrease in insulin secretion. ${ }^{55,126}$ Coupled with the observation that treatment with GHSs, particularly the nonpeptidyl derivatives, induces hyperglycemia and insulin resistance in the elderly and in obese human patients, those findings suggest that ghrelin has an important role in the regulation of insulin secretion and glucose metabolism. ${ }^{128,129}$

In healthy humans, hyperglycemia suppresses both baseline plasma concentrations of $\mathrm{GH}$ and $\mathrm{GH}$ release induced by GHRH. ${ }^{130}$ The mechanism of the hyperglycemia-induced decrease in circulating $\mathrm{GH}$ is unclear. Acute hyperglycemia substantially decreases plasma ghrelin concentrations in healthy humans. ${ }^{131}$ Because ghrelin markedly stimulates GH secretion, the hyperglycemia-induced suppression of GH release may be caused, at least partly, by the decrease in plasma ghrelin concentrations. ${ }^{131}$

\section{Cardiovascular Effects}

Ghrelin receptors are widely distributed in cardiovascular tissues. In humans and rats, GHS-R la mRNA has been detected primarily in the heart, coronary arteries, and aorta. ${ }^{48,132}$ Ghrelin is synthesized and secreted by isolated human cardiomyocytes, in which it likely has paracrine or autocrine effects and may protect the cells from apoptosis. ${ }^{133}$

Growth hormone improves cardiac performance in experimentally induced heart failure. ${ }^{134,135}$ In 1 study, ${ }^{81}$ prolonged treatment with GHSs protected aged rats against cardiovascular damage and improved cardiac performance after myocardial infarction, and enhanced left ventricular contractility in pigs with dilated cardiomyopathy. Long-term ghrelin administration improves cardiac contractility and cardiac output and reduces systemic vascular resistance in humans with chronic heart failure. ${ }^{132}$ Furthermore, it induces myocardial growth, improving the structure and function of the left ventricle. ${ }^{136,137}$ Interestingly, hexarelin, acylated ghrelin, and even unacylated ghrelin all prevent doxorubicin-induced death in cultured cardiomyocytes. ${ }^{138}$ Because unacylated ghrelin does not activate the GHS-R $1 \mathrm{a},{ }^{54}$ these data indicate that another subtype of GHS-R exists in cardiac tissue and that unacylated ghrelin has some biological activity. ${ }^{81}$ Thus, long-term administration of ghrelin may become a treatment strategy for patients with heart failure. ${ }^{136}$

\section{Antiproliferative Effects}

Growth hormone secretagogue receptors are also found in human neoplastic tissues, such as mammary gland tumors and thyroid carcinoma cells. ${ }^{139,140}$ Ghrelin 
and GHSs inhibit cell proliferation in thyroid tumor cells ${ }^{140,141}$ and breast cancer cells. ${ }^{138}$ Nonacylated ghrelin also exerts antiproliferative actions. ${ }^{139}$ Because unacylated ghrelin is unable to bind to the GHS-R la, these data suggest that the antiproliferative effects of acylated and unacylated ghrelin on cancer cells are mediated via a GHS-R subtype that is different from GHS-R la. ${ }^{142}$

\section{Conclusion}

The isolation and characterization of ghrelin are landmarks in GH research and represent a major advancement in our understanding of GH regulation. Ghrelin is a gastric peptide that is active in the CNS, where it is involved in regulation of GH secretion and control of food intake. The widespread expression of GHS-Rs in central and peripheral tissues suggests that ghrelin may have many endocrine, paracrine, and possibly autocrine effects. Future challenges lie in improving our ability to diagnose and treat the different diseases associated with altered GH secretion. For example, the potential use of ghrelin in GH deficiency warrants investigation. In addition, ghrelin or ghrelin analogs may be useful in pathologic catabolic states such as wound and fracture healing, osteoporosis, severe burns, sepsis, excessive inflammation, multiple organ failure, and weakness in critically ill patients, all conditions in which the administration of moderate doses of GH has been effective. ${ }^{143,144}$ The orexigenic actions of ghrelin and its analogs may be harnessed to treat the pathologic forms of anorexia that accompany cancer and aging. ${ }^{145}$ Whether ghrelin antagonists can be used to reduce food intake and be developed as a treatment for obesity remains to be investigated.

\section{References}

1. Plotsky PM, Vale W. Patterns of growth hormone-releasing factor and somatostatin secretion into the hypophysial-portal circulation of the rat. Science 1985;230:461-463.

2. Tannenbaum GS, Ling N. The interrelationship of growth hormone releasing factor and somatostatin in generation of the ultradian rhythm of growth hormone secretion. Endocrinology 1984;115:1952-1957.

3. Kooistra HS, den Hertog E, Okkens AC, et al. Pulsatile secretion pattern of growth hormone during the luteal phase and mid-anoestrus in beagle bitches. J Reprod Fertil 2000;119:217-222.

4. Frohman LA, Downs TR, Chomzsynski P. Regulation of growth hormone secretion. Front Neuroendocrinol 1992;13:344-405.

5. Ho KY, Veldhuis JD, Johnson ML. Fasting enhances growth hormone secretion and amplifies the complex rhythms of growth hormone secretion in man. J Clin Invest 1988;81:968-975.

6. Van Cauter E, Plat L, Copinschi G. Interrelations between sleep and the somatotropic axis. Sleep 1998;21:553-566.

7. Vigneri R, Squatrito S, Pezzino V, et al. Growth hormone levels in diabetes: correlation with the clinical control of the disease. Diabetes 1976;25:167-172.

8. Kojima M, Hosoda H, Date Y, et al. Ghrelin is a growth-hormone-releasing acylated peptide from stomach. Nature 1999;402:656-660.

9. Wallis M. The molecular evolution of pituitary growth hormone, prolactin and placental lactogen: a protein family showing variable rates of evolution. J Mol Evol 1981;17:10-18.

10. Xu BC, Wang X, Darus CJ, et al. Growth hormone promotes the association of transcription factor STAT5 with the growth hormone receptor. J Biol Chem 1996;271:19768-19773.

11. Barnard R, Waters MJ. The serum growth hormone binding protein: pregnant with possibilities. J Endocrinol 1997;153:1-14
12. Eigenmann JE, Patterson DF, Froesch ER. Body size parallels insulin-like growth factor I levels but not growth hormone secretory capacity. Acta Endocrinol (Copenh) 1984;106:448-453.

13. Casanueva FF. Physiology of growth hormone secretion and action. Endocrinol Metab Clin North Am 1992;21:483-517.

14. Carrel AL, Allen DB. Effects of growth hormone on body composition and bone metabolism. Endocrine 2000;12:163-172.

15. Daughaday WH, Hall K, Raben MS, et al. Somatomedin proposed designation for sulphation factor. Nature 1972;235:107.

16. Tamura K, Kobayashi M, Ishii Y, et al. Primary structure of rat insulin-like growth factor-I and its biological activities. J Biol Chem 1989;264:5616-5621

17. Ceda GP, Davis RG, Rosenfeld RG, et al. The growth hormone (GH)-releasing hormone (GHRH)-GH-somatomedin axis: evidence for rapid inhibition of GHRH-elicited GH release by insulinlike growth factors I and II. Endocrinology 1987;120:1658-1662.

18. Pelligrini E, Bluet-Pajot MT, Mounier F, et al. Central administration of a growth hormone $(\mathrm{GH})$ receptor mRNA antisense increases GH pulsatility and decreases hypothalamic somatostatin expression in rats. J Neurosci 1996;16:8140-8148.

19. Bowers CY, Chang J, Momany FA, et al. Effect of the enkephalins and enkephalin analogs on release of pituitary hormones in vitro. Mol Endocrinol 1977;287-292.

20. Bowers CY, Momany FA, Reynolds GA, et al. On the in vitro and in vivo activity of a new synthetic hexapeptide that acts on the pituitary to specifically release growth hormone. Endocrinology 1984;114:1537-1545.

21. Smith RG, Van der Ploeg LH, Howard AD, et al. Peptidomimetic regulation of growth hormone secretion. Endocr Rev 1997;18:621-645.

22. Ghigo E, Arvat E, Gianotti L, et al. Growth hormone-releasing activity of hexarelin, a new synthetic hexapeptide, after intravenous, subcutaneous, intranasal, and oral administration in man J Clin Endocrinol Metab 1994;78:693-698.

23. Chapman IM, Bach MA, Van Cauter E, et al. Stimulation of the growth hormone (GH)-insulin-like growth factor I axis by daily oral administration of a GH secretogogue (MK-677) in healthy elderly subjects. J Clin Endocrinol Metab 1996;81:4249-4257.

24. Casanueva FF, Dieguez C. Growth hormone secretagogues: physiological role and clinical utility. Trends Endocrinol Metab 1999; 10:30-38.

25. Laron Z. Growth hormone secretagogues. Clinical experience and therapeutic potential. Drugs 1995;50:595-601.

26. Jacks T, Smith R, Judith F, et al. MK-0677, a potent, novel, orally active growth hormone (GH) secretagogue: $\mathrm{GH}$, insulin-like growth factor I, and other hormonal responses in beagles. Endocrinology 1996;137:5284-5289.

27. Hayashida T, Murakami K, Mogi K, et al. Ghrelin in domestic animals: distribution in stomach and its possible role. Domest Anim Endocrinol 2001;21:17-24.

28. Bhatti SFM, De Vliegher SP, Van Ham L, et al. Effects of growth hormone-releasing peptides in healthy dogs and in dogs with pituitary-dependent hyperadrenocorticism. Mol Cell Endocrinol 2002;197:97-103.

29. Bhatti SFM, Duchateau L, Van Ham LML, et al. Effects of growth hormone secretagogues on the release of adenohypophyseal hormones in young and old healthy dogs. Vet J 2006; in press.

30. Massoud AF, Hindmarsh PC, Brook DGD. Hexarelininduced growth hormone, cortisol and prolactin release: a doseresponse study. J Clin Endocrinol Metab 1996;81:4338-4341.

31. Arvat E, Maccario M, Di Vito L, et al. Endocrine activities of ghrelin, a natural growth hormone secretagogue (GHS), in humans: comparison and interactions with hexarelin, a nonnatural peptidy GHS, and GH-releasing hormone. J Clin Endocrinol Metab 2001;86:1169-1174.

32. Raun K, Hansen BS, Johansen NL, et al. Ipamorelin, the first selective growth hormone secretagogue. Eur J Endocrinol 1998; 139:552-561.

33. Broglio F, Koetsveld PVP, Benso A, et al. Ghrelin secretion is inhibited by either somatostatin or cortistatin in humans. J Clin Endocrinol Metab 2002;87:4829-4832.

34. Guillemin R, Brazeau P, Bohlen P, et al. Growth hormonereleasing factor from a human pancreatic tumor that caused acromegaly. Science 1982;218:585-587. 
35. Rivier J, Spiess J, Thorner MO, et al. Characterisation of a growth hormone-releasing factor from a human pancreatic islet tumour. Nature 1982;300:276-278.

36. Howard AD, Feighner SD, Cully DF, et al. A receptor in pituitary and hypothalamus that functions in growth hormone release. Science 1996;273:974-977.

37. Guan XM, Yu H, Palyha OC, et al. Distribution of mRNA encoding the growth hormone secretagogue receptor in brain and peripheral tissues. Brain Res Mol Brain Res 1997;48:23-29.

38. Bowers CY, Reynolds GA, Durham D, et al. Growth hormone (GH)-releasing peptide stimulates $\mathrm{GH}$ release in normal men and acts synergistically with GH-releasing hormone. J Clin Endocrinol Metab 1990;70:975-982.

39. Pong S-S, Chaung L-YP, Dean DC, et al. Identification of a new G-protein-linked receptor for growth hormone secretagogues. Mol Endocrinol 1996;10:57-61.

40. McKee KK, Tan CP, Palyha OC, et al. Cloning and characterization of two human $G$ protein-coupled receptor genes (GPR38 and GPR39) related to the growth hormone secretagogue and neurotensin receptors. Genomics 1997;46:426-434.

41. McKee KK, Palyha OC, Feighner SD, et al. Molecular analysis of rat pituitary and hypothalamic growth hormone secretagogue receptors. Mol Endocrinol 1997;11:415-423.

42. Palyha OC, Feighner SD, Tan CP, et al. Ligand activation domain of human orphan growth hormone $(\mathrm{GH})$ secretagogue receptor (GHS-R) conserved from Pufferfish to humans. Mol Endocrinol 2000;14:160-169.

43. Shuto Y, Shibasaki T, Wada K, et al. Generation of polyclonal antiserum against the growth hormone secretagogue receptor (GHS-R): evidence that the GHS-R exists in the hypothalamus, pituitary and stomach of rats. Life Sci 2001;68:991-996.

44. Cheng K, Chan WW, Butler B, et al. Stimulation of growth hormone release from rat primary pituitary cells by L-692,429, a nove non-peptidyl GH secretagogue. Endocrinology 1993;132:2729-2731.

45. Dickson SL, Leng G, Dyball RE, et al. Central actions of peptide and non-peptide growth hormone secretagogues in the rat. Neuroendocrinology 1995;61:36-43.

46. Papotti M, Ghé C, Cassoni P, et al. Growth hormone secretagogue binding sites in peripheral human tissues. J Clin Endocrinol Metab 2000;85:3803-3807.

47. Kojima M, Hosoda H, Kangawa K. Purification and distribution of ghrelin: the natural ligand for the growth hormone secretagogue receptor. Horm Res 2001;56:93-97.

48. Gnanapavan S, Kola B, Bustin SA, et al. The tissue distribution of the mRNA of ghrelin and subtypes of its receptor, GHS-R, in humans. J Clin Endocrinol Metab 2002;87:2988.

49. Casanueva FF, Dieguez C. Ghrelin: the link connecting growth with metabolism and energy homeostasis. Rev Endocr Metab Disord 2002;3:325-338.

50. Tomasetto $\mathrm{C}$, Wendling $\mathrm{C}$, Rio $\mathrm{M}-\mathrm{C}$, et al. Identification of cDNA encoding motilin related peptide/ghrelin precursor from dog fundus. Peptides 2001;22:2055-2059.

51. Date Y, Kojima M, Hosoda H, et al. Ghrelin, a novel growth hormone-releasing acylated peptide, is synthesized in a distinct endocrine cell type in the gastrointestinal tracts of rats and humans Endocrinology 2000;141:4255-4261.

52. van der Lely AJ, Tschop M, Heiman ML, et al. Biological, physiological, pathophysiological, and pharmacological aspects of ghrelin. Endocr Rev 2004;25:426-457.

53. Hosoda H, Kojima M, Matsuo H, et al. Purification and characterization of rat des-Gln 14-ghrelin, a second endogenous ligand for the growth hormone secretagogue receptor. J Biol Chem 2000;275:21995-22000.

54. Bednarek MA, Feighner SD, Pong SS, et al. Structure-function studies on the new growth hormone-releasing peptide, ghrelin minimal sequence of ghrelin necessary for activation of growth hormone secretagogue receptor la. J Med Chem 2000;43:4370-4376.

55. Broglio F, Gottero C, Arvat E, et al. Endocrine and nonendocrine actions of ghrelin. Horm Res 2003;59:109-117.

56. Horvath T, Diano S, Sotonyi P, et al. Mini review: ghrelin and the regulation of energy balance-a hypothalamic perspective. Endocrinology 2001;142:4163-4169.

57. Cassoni P, Ghe C, Marrocco T, et al. Expression of ghrelin and biological activity of specific receptors for ghrelin and des-acyl ghrelin in human prostate neoplasms and related cell lines. Eur J Endocrinol 2004;150:173-184.

58. Korbonits M, Kojima M, Kangawa K, et al. Presence of ghrelin in normal and adenomatous human pituitary. Endocrine 2001;14:101-104.

59. Mori K, Yoshimoto A, Takaya K, et al. Kidney produces a novel acylated peptide, ghrelin. FEBS Lett 2000;486:213-216.

60. Gualillo O, Caminos J, Blanco M, et al. Ghrelin, a novel placental-derived hormone. Endocrinology 2001;142:788-794

61. Barreiro ML, Gaytan F, Caminos JE, et al. Cellular location and hormonal regulation of ghrelin expression in rat testis. Biol Reprod 2002;67:1768-1776.

62. Kanamoto N, Akamizu T, Hosoda H, et al. Substantial production of ghrelin by a human medullary thyroid carcinoma cell line. J Clin Endocrinol Metab 2001;86:4984-4990.

63. Volante M, Allia E, Gugliotta P, et al. Expression of ghrelin and of growth hormone secretagogue receptor by pancreatic islet cells and related endocrine tumors. J Clin Endocrinol Metab 2002;87:1300-1308.

64. Volante M, Fulcheri E, Allia E, et al. Ghrelin expression in fetal, infant, and adult human lung. J Histochem Cytochem 2002;50:1013-1021.

65. Gaytan F, Barreiro ML, Chopin LK, et al. Immunolocalization of ghrelin and its functional receptor, the type la growth hormone secretagogue receptor, in the cyclic human ovary. J Clin Endocrinol Metab 2003;88:879-887.

66. Hattori N, Saito T, Yagyu T, et al. GH, GH receptor, GH secretagogue receptor, and ghrelin expression in human $\mathrm{T}$ cells, B cells and neutrophils. J Clin Endocrinol Metab 2001;86:4284-4291.

67. Ariyasu H, Takaya K, Tagami T, et al. Stomach is a major source of circulating ghrelin, and feeding state determines plasma ghrelin-like immunoreactivity levels in humans. J Clin Endocrinol Metab 2001;86:4753-4758

68. Hosoda H, Kojima M, Mizushima T, et al. Structural divergence of human ghrelin. Identification of multiple ghrelin-derived molecules produced by post-translational processing. J Biol Chem 2003;278:64-70

69. Moller N, Nygren J, Hansen TK, et al. Splanchnic release of ghrelin in humans. J Clin Endocrinol Metab 2003;88:850-852.

70. Arvat E, Di Vito 1, Broglio F, et al. Preliminary evidence that ghrelin, the natural growth hormone secretagogue receptor ligand, strongly stimulates GH secretion in humans. J Endocrinol Invest 2000;23:493-495.

71. Seoane LM, Tovar S, Baldelli R, et al. Ghrelin elicits a marked stimulatory effect on $\mathrm{GH}$ secretion in freely-moving rats. Eur J Endocrinol 2000;143:R7-R9.

72. Takaya K, Ariyasu H, Kanamoto N, et al. Ghrelin strongly stimulates growth hormone release in humans. J Clin Endocrinol Metab 2000;85:4908-4911.

73. Ghigo E, Arvat E, Giordano R, et al. Biologic activities of growth hormone secretagogues in humans. Endocrine 2001;14:87-93.

74. Tannenbaum GS, Bowers CY. Interactions of growth hormone secretagogues and growth hormone-releasing hormone/somatostatin. Endocrine 2001;14:21-27.

75. Hickey GJ, Drisko J, Faidley T, et al. Mediation by the central nervous system is critical to the in vivo activity of the GH secretagogue L-692,585. J Endocrinol 1996;148:371-380.

76. Popovic V, Miljic D, Micic C, et al. Ghrelin main action on the regulation of growth hormone release is exerted at hypothalamic level. J Clin Endocrinol Metab 2003;88:3450-3453.

77. Bowers CY, Sartor AO, Reynolds GA, et al. On the actions of the growth hormone-releasing hexapeptide, GHRP. Endocrinology 1991;128:2027-2035.

78. Arvat E, di Vito L, Maccagno B, et al. Effects of GHRP-2 and hexarelin, two synthetic GH-releasing peptides, on GH, prolactin, ACTH and cortisol levels in man. Comparison with the effects of GHRH, TRH and hCRH. Peptides 1997;18:885-891.

79. Peino R, Baldelli R, Rodriguez-Garcia J, et al. Ghrelininduced growth hormone secretion in humans. Eur J Endocrinol 2000;143:R11-R14.

80. Renner U, Brockmeier S, Strasburger CJ, et al. Growth hormone $(\mathrm{GH})$-releasing peptide stimulation of $\mathrm{GH}$ release from human somatotroph adenoma cells: interaction with GH-releasing hormone, 
thyrotropin-releasing hormone, and octreotide. J Clin Endocrino Metab 1994;78:1090-1096.

81. Muccioli G, Tschop M, Papotti M, et al. Neuroendocrine and peripheral activities of ghrelin: implications in metabolism and obesity. Eur J Pharmacol 2002;440:235-254.

82. Frawley LS, Boockfor FR. Mammosomatotropes: presence and functions in normal and neoplastic pituitary tissue. Endocr Rev 1991;12:337-355.

83. Loche S, Cambiaso P, Merola B, et al. The effect of hexarelin on growth hormone $(\mathrm{GH})$ secretion in patients with GH deficiency. J Clin Endocrinol Metab 1995;80:2692-2696.

84. Thomas GB, Fairhall KM, Robinson ICAF. Activation of the hypothalamo-pituitary-adrenal axis by the growth-hormone (GH) secretagogue, GH-releasing peptide-6, in rats. Endocrinology 1997;138:1585-1591

85. Korbonits M, Kaltsas G, Perry LA, et al. The GHS hexarelin stimulates the hypothalamo-pituitary-adrenal axis via AVP. J Clin Endocrinol Metab 1999;84:2489-2495.

86. Arvat E, Di Vito L, Broglio F, et al. Preliminary evidence that ghrelin, the natural GH secretagogue (GHS)-receptor ligand, strongly stimulates GH secretion in humans. $J$ Endocrinol Invest 2000;23:493-495.

87. Tschop M, Smiley DL, Heiman ML. Ghrelin induces adiposity in rodents. Nature 2000;407:908-913.

88. Wren AM, Small CJ, Ward HL, et al. The novel hypothalamic peptide ghrelin stimulates food intake and growth hormone secretion. Endocrinology 2000;141:4325-4328.

89. Shintani M, Ogawa Y, Ebihara K, et al. Ghrelin, an endogenous growth hormone secretagogue, is a novel orexigenic peptide that antagonizes leptin action through the activation of hypothalamic neuropeptide Y/Y1 receptor pathway. Diabetes 2001;50:227-232.

90. Toogood AA, Thorner MO. Ghrelin, not just another growth hormone secretagogue. Clin Endocrinol (Oxf) 2001;55:589-591.

91. Friedman JM, Halaas JL. Leptin and the regulation of body weight in mammals. Nature 1998;395:763-770.

92. Miner JL. The adipocyte as an endocrine cell. J Anim Sci 2004;82:935-941.

93. Zhang Y, Proenca R, Maffei M, et al. Positional cloning of the mouse obese gene and its human analogue. Nature 1994;372:425-432.

94. Neary NM, Small CJ, Bloom SR. Gut and mind. Gut 2003;52:918-921

95. Bowers CY. Unnatural growth hormone-releasing peptide begets natural ghrelin. J Clin Endocrinol Metab 2001;86:1464-1469.

96. Spiegelman BM, Flier JS. Obesity and the regulation of energy balance. Cell 2001;104:531-543.

97. Farooqi IS, Jebb SA, Langmack G, et al. Effects of recombinant leptin therapy in a child with congenital leptin deficiency. N Engl J Med 1999;341:879-884.

98. Dickson SL, Luckman SM. Induction of c-fos messenger ribonucleic acid in neuropeptide $\mathrm{Y}$ and growth hormone (GH)releasing factor neurons in the rat arcuate nucleus following systemic injection of the GH secretagogue, GH-releasing peptide-6. Endocrinology 1997;138:771-777.

99. Kamegai J, Tamura H, Shimizu T, et al. Chronic central infusion of ghrelin increases hypothalamic neuropeptide $\mathrm{Y}$ and agouti-related protein mRNA levels and body weight in rats. Diabetes 2001;50:2438-2443.

100. Hewson AK, Dickson SL. Systemic administration of ghrelin induces Fos and Egr-1 proteins in the hypothalamic arcuate nucleus of fasted and fed rats. J Neuroendocrinol 2000;12:1047-1049.

101. Cowley MA, Smith RG, Diano S, et al. The distribution and mechanism of action of ghrelin in the CNS demonstrates a novel hypothalamic circuit regulating energy homeostasis. Neuron 2003:37:649-661.

102. Kohno D, Gao HZ, Muroya S, et al. Ghrelin directly interacts with neuropeptide-Y-containing neurons in the rat arcuate nucleus: $\mathrm{Ca}^{2+}$ signaling via protein kinase $\mathrm{A}$ and $\mathrm{N}$-type channeldependent mechanisms and cross-talk with leptin and orexin. Diabetes 2003;52:948-956.

103. Olszewski PK, Li D, Grace MK, et al. Neural basis of orexigenic effects of ghrelin acting within lateral hypothalamus. Peptides 2003;24:597-602

104. Riediger T, Traebert M, Schmid HA, et al. Site-specific effects of ghrelin on the neuronal activity in the hypothalamic arcuate nucleus. Neurosci Lett 2003;341:151-155.

105. Seoane LM, Lopez M, Tovar S, et al. Agouti-related peptide, neuropeptide $\mathrm{Y}$, and somatostatin-producing neurons are targets for ghrelin actions in the rat hypothalamus. Endocrinology 2003;144:544-551.

106. Tschop M, Weyer C, Tataranni PA, et al. Circulating ghrelin levels are decreased in human obesity. Diabetes 2001;50:707-709.

107. Cummings E, Purnell JQ, Frayo SR, et al. A preprandial rise in plasma ghrelin levels suggests a role in meal initiation in humans Diabetes 2001;50:1714-1719.

108. Sugino T, Yamaura J, Yamagishi M, et al. A transient surge of ghrelin secretion before feeding is modified by different feeding regimens in sheep. Biochem Biophys Res Commun 2002;298:785-788.

109. Bowers CY. Editorial: a new dimension on the induced release of growth hormone in obese subjects. J Clin Endocrinol Metab 1993;76:817-818.

110. Dieguez C, Casanueva F. Influence of metabolic substrates and obesity on growth hormone secretion. Trends Endocrinol Metab 1995;6:55-59.

111. Tolle V, Bassant MH, Zizzari P, et al. Ultradian rhythmicity of ghrelin secretion in relation with $\mathrm{GH}$, feeding behavior, and sleepwake patterns in rats. Endocrinology 2002;143:1353-1361.

112. Banks WA, Tschop M, Robinson SM, et al. Extent and direction of ghrelin transport across the blood-brain barrier is determined by its unique primary structure. J Pharmacol Exp Ther 2002;302:822-827.

113. Masuda Y, Tanaka T, Inomata M, et al. Ghrelin stimulates gastric acid secretion and motility in rats. Biochem Biophys Res Commun 2000;276:905-908

114. Asakawa A, Inui A, Kaga T, et al. Ghrelin is an appetitestimulatory signal from stomach with structural resemblance to motilin. Gastroenterology 2001;120:337-345.

115. Folwaczny C, Chang JK, Tschop M. Ghrelin and motilin: two sides of one coin? Eur J Endocrinol 2001;144:R1-R3.

116. Garthwaite TL. Peripheral motilin administration stimulates feeding in fasted rats. Peptides 1985;6:41-44.

117. Samson WK, Lumpkin MD, Nilaver G, et al. Motilin: a novel growth hormone releasing agent. Brain Res Bull 1984;12:57-62.

118. Feighner SD, Tan CP, McKee KK, et al. Receptor for motilin identified in the human gastrointestinal system. Science 1999;284:2184-2188.

119. Brown JC, Mutt V, Dryburgh JR. The further purification of motilin, a gastric motor activity stimulating polypeptide from the mucosa of the small intestine of dogs. Can J Physiol Pharmacol 1971;49:399-405.

120. Itoh Z. Motilin and clinical application. Peptides 1997;18:593-608.

121. Date Y, Nakazato M, Hashiguchi S, et al. Ghrelin is present in pancreatic $\alpha$-cells of humans and rats and stimulates insulin secretion. Diabetes 2002;51:124-129.

122. Rindi G, Necchi V, Savio A, et al. Characterisation of gastric ghrelin cells in man and other mammals: studies in adult and fetal tissues. Histochem Cell Biol 2002;117:511-519.

123. Wierup N, Svensson H, Mulder H, et al. The ghrelin cell: a novel developmentally regulated islet cell in the human pancreas. Regul Pept 2002;107:63-69.

124. Lee HM, Wang G, Englander EW, et al. Ghrelin, a new gastrointestinal endocrine peptide that stimulates insulin secretion: enteric distribution, ontogeny, influence of endocrine, and dietary manipulations. Endocrinology 2002;143:185-190.

125. Caixas A, Bashore C, Nash W, et al. Insulin, unlike food intake, does not suppress ghrelin in human subjects. J Clin Endocrinol Metab 2002;87:1902.

126. Broglio F, Arvat E, Benso A, et al. Ghrelin, a natural GH secretagogue produced by the stomach, induces hyperglycemia and reduces insulin secretion in humans. J Clin Endocrinol Metab 2001; 86:5083-5086.

127. Adeghate E, Ponery AS. Ghrelin stimulates insulin secretion from the pancreas of normal and diabetic rats. J Neuroendocrino 2002;14:555-560.

128. Svensson J, Lonn L, Jansson JO, et al. Two-month treatment of obese subjects with the oral GH secretagogue MK-677 increases GH secretion, fat-free mass, and energy expenditure. J Clin Endocrinol Metab 1998;83:362-369. 
129. Muller AF, Janssen JA, Hofland LJ, et al. Blockade of the growth hormone $(\mathrm{GH})$ receptor unmasks rapid GH-releasing peptide-6-mediated tissue-specific insulin resistance. J Clin Endocrinol Metab 2001;86:590-593.

130. Masuda A, Shibasaki T, Nakahara M, et al. The effect of glucose on growth hormone (GH)-releasing hormone-mediated GH secretion in man. J Clin Endocrinol Metab 1985;60:523-526.

131. Nakagawa E, Nagaya N, Okumura H, et al. Hyperglycaemia suppresses the secretion of ghrelin, a novel growth-hormone-releasing peptide: responses to the intravenous and oral administration of glucose. Clin Sci (Lond) 2002;103:325-328.

132. Nagaya N, Miyatake K, Uematsu M, et al. Hemodynamic, renal, and hormonal effects of ghrelin infusion in patients with chronic heart failure. J Clin Endocrinol Metab 2001;86:5854-5859.

133. Iglesias MJ, Pineiro R, Blanco M, et al. Growth hormone releasing peptide (ghrelin) is synthesized and secreted by cardiomyocytes. Cardiovasc Res 2004;62:481-488.

134. Yang R, Bunting S, Gillet N, et al. Growth hormone improves cardiac performance in experimental heart failure. Circulation 1995;92:262-267.

135. Fazio S, Sabatini D, Capaldo B, et al. A preliminary study of growth hormone in the treatment of dilated cardiomyopathy. N Engl J Med 1996;334:809-814.

136. Nagaya N, Kangawa K. Ghrelin, a novel growth hormonereleasing peptide, in the treatment of chronic heart failure. Regul Pept 2003;114:71-77.

137. Nagaya N, Moriya J, Yasumura Y, et al. Effects of ghrelin administration on left ventricular function, exercise capacity, and muscle wasting in patients with chronic heart failure. Circulation 2004:110:3674-3679.

138. Filigheddu N, Fubini A, Baldanzi G, et al. Hexarelin protects $\mathrm{H} 9 \mathrm{c} 2$ cardiomyocytes from doxorubicin-induced cell death Endocrine 2001;14:113-119.

139. Cassoni P, Papotti M, Ghe C, et al. Identification, characterization, and biological activity of specific receptors for natural (ghrelin) and synthetic growth hormone secretagogues and analogs in human breast carcinomas and cell lines. J Clin Endocrinol Metab 2001;86:1738-1745.

140. Kanamoto N, Akamizu T, Hosoda H, et al. Substantial production of ghrelin by a human medullary thyroid carcinoma cell line. J Clin Endocrinol Metab 2001;86:4984-4990.

141. Cassoni P, Muccioli G, Marrocco T, et al. Cortistatin-14 inhibits cell proliferation of human thyroid carcinoma cell lines of both follicular and parafollicular origin. J Endocrinol Invest 2002;25:362-368.

142. Muccioli G, Papotti M, Locatelli V, et al. Binding of 125Ilabeled ghrelin to membranes from human hypothalamus and pituitary gland. J Endocrinol Invest 2001;24:RC7-RC9.

143. van den Berghe G. Novel insights into the neuroendocrinology of critical illness. Eur J Endocrinol 2000;143:1-13.

144. Petersenn S. Growth hormone secretagogues and ghrelin: an update on physiology and clinical relevance. Horm Res 2002;58:56-61.

145. Torsello A, Luoni M, Schweiger F, et al. Novel hexarelin analogs stimulate feeding in the rat through a mechanism not involving growth hormone release. Eur J Pharmacol 1998;360:123-129. 